\title{
ENTREPRENEURIAL ACTIVITY OF INDIVIDUALS AND LEGAL ENTITIES IN THE RUSSIAN FEDERATION
}

\author{
Tatyana Skvortsova ${ }^{1}$, Anna Nikitina $^{2}$, Mustafa Ansari $^{3}$, Margarita Tertyshnikova $^{4}$
}

\begin{abstract}
Entrepreneurial activity is pursued by large, medium and small business entities which can be introduced by individuals - individual entrepreneurs and legal entities - commercial and non-profit organizations. The entrepreneurial activity of these entities is regulated by the rules of law which may cause problems in law enforcement resulting in the improvement of legal regulation. The article provides a review of some legal regulation issues of entrepreneurial activities of non-profit organizations, the analysis of peculiarities of economic activity exercised by these organizations and covers the problems of differentiation between entrepreneurial and non-entrepreneurial activities that individuals are engaged in. The authors analyze the problem of relations between the concepts of "entrepreneurial activity" and "income-generating activities" which requires a solution by means of elaborating a strategy for existing legislation improvement to prevent situations that violate the rights and legal interests of entities in the sphere of entrepreneurial activity.
\end{abstract}

JEL Classification Numbers: K19, O17; DOI: http://dx.doi.org/10.12955/cbup.v6.1196

Keywords: entrepreneurial activity, income-generating activities, large, medium and small business entities, commercial organizations, non-profit organizations

\section{Introduction}

To ensure sustainable development of the economy and its effective improvement, two factors have crucial importance. The first factor is the reliance on law, legislation and the creation of legislation that adequately reflects the processes occurring in the economy, ensuring maximum protection of the rights and legitimate interests of entrepreneurs. The second factor presupposes steady implementation and the implementation of legislation. It is also necessary to take into account private and public interests in the regulation of entrepreneurship (Shatkovskaya \& Epifanova, 2016).

At the same time, in the current context of the lack of sufficiently comprehensive legislation on entrepreneurial activity and the common practice of its implementation in Russia, the cases of violating the rights and interests of business entities are inevitable.

Some problems of legal regulation of entrepreneurial activity by individual entities will be considered in the article to develop directions for improving current legislation which would prevent situations violating their rights and legitimate interests.

\section{Large, medium and small business entities in Russia}

The modern understanding of entrepreneurship as an economic category is based on many opinions. As a rule, entrepreneurship is considered along with labor, land, and capital as a factor of production (Kolesnikov et al., 2016).

Small, medium and large businesses are distinguished. The main function of large business concludes in the fact that these companies provide a high market economy to the country and the world. They produce the bulk of products. In general, there are three reasons for the growth of such companies:

1. The company's desire to save resources in production. This is achieved by increasing output and reducing costs. The company achieves such results due to increasing labor productivity, upgrading the skills of workers and introducing automatic equipment.

2. Increasing the diversity of products and expanding the scope of activities. Large world companies are formed by means of this method. To form such corporations, the tools of vertical integration and diversification are used.

3. Savings on transaction costs which are associated with the fact that there is a transfer of goods from one technological structure to another. Reduction of costs is achieved by means of vertical integration and diversification.

\footnotetext{
${ }^{1}$ Department of civil law, Rostov State University of Economics, Rostov-on-Don, Russian Federation, tas242@yandex.ru

${ }^{2}$ Department of civil law, Rostov State University of Economics, Rostov-on-Don, Russian Federation, oooytsrostov@rambler.ru

${ }^{3}$ Rostov State University of Economics, Rostov-on-Don, Russian Federation, mustafa_007ru@yahoo.com

${ }^{4}$ Rostov State University of Economics, Rostov-on-Don, Russian Federation, mpsaratsyn@ gmail.com.
} 
However, large business like any other business also has its disadvantages. With the growth of the firm, the effectiveness of its management is reduced. Many types of large business have an inflexible system since they can regulate the demand and prices for manufactured products.

The sphere of activity of large business is the extraction and processing of raw materials, production (as the main type of activity), wholesale trade, which is more accurately called supplies and other activities. Table 1 presents the number of organizations (legal entities) and their geographically separated units in the Russian Federation by types of economic activity (organizations without small businesses, budget organizations, banks, insurance and other financial and credit organizations) in 2016.

Table 1: Number of organizations (legal entities) and their geographically separated units in the Russian Federation by types of economic activity (organizations without small businesses, budget organizations, banks, insurance and other financial and credit organizations) in 2016

\begin{tabular}{|c|c|c|}
\hline Type & $\begin{array}{l}\text { The Number of } \\
\text { organizations (legal entities) }\end{array}$ & $\begin{array}{l}\text { Number of } \\
\text { geographically } \\
\text { separate units }\end{array}$ \\
\hline Total number of organizations (legal entities) & 83333 & 167552 \\
\hline \multicolumn{3}{|l|}{ Including by economic activity } \\
\hline agriculture, hunting and forestry & 5322 & 7129 \\
\hline fishing & 249 & 280 \\
\hline mining and quarrying & 1542 & 3590 \\
\hline mining of energy producing minerals & 867 & 2617 \\
\hline mining except of energy producing minerals & 675 & 973 \\
\hline manufacturing & 13695 & 21691 \\
\hline manufacture of food products, including beverages, and tobacco & 2694 & 4916 \\
\hline manufacture of textiles and textile products & 435 & 651 \\
\hline manufacture of leather, leather products and footwear & 104 & 136 \\
\hline manufacture of wood and wood products & 404 & 570 \\
\hline $\begin{array}{l}\text { manufacture of pulp, paper and paper products; publishing and } \\
\text { printing }\end{array}$ & 1542 & 1959 \\
\hline manufacture of coke and refined petroleum products & 122 & 258 \\
\hline manufacture of chemical products & 731 & 1161 \\
\hline manufacture of rubber and plastics products & 577 & 777 \\
\hline manufacture of other non-metallic mineral products & 1250 & 1602 \\
\hline manufacture of basic metals and fabricated metal products & 1333 & 1971 \\
\hline $\begin{array}{l}\text { manufacture of machinery and equipment (except of weapons and } \\
\text { ammunition) }\end{array}$ & 1382 & 2259 \\
\hline manufacture of electrical, electronic and optical equipment & 1538 & 2305 \\
\hline manufacture of transport vehicles and transport equipment & 853 & 1555 \\
\hline other manufacturing & 544 & 1273 \\
\hline electricity, gas, and water supply & 5937 & 12172 \\
\hline construction & 4707 & 8454 \\
\hline $\begin{array}{l}\text { wholesale and retail trade; repair of motor vehicles, motorcycles } \\
\text { and personal and household goods }\end{array}$ & 12680 & 50972 \\
\hline hotels and restaurants & 1521 & 3052 \\
\hline transport and communications & 5096 & 14459 \\
\hline real estate, renting and business activities & 19224 & 28871 \\
\hline public administration and defense, compulsory social security & 86 & 231 \\
\hline education & 5705 & 6434 \\
\hline health and social work & 1482 & 2358 \\
\hline other community, social and personal service activities & 6086 & 7858 \\
\hline
\end{tabular}

A small enterprise is an enterprise that does not dominate in its field. Micro-enterprises are very small businesses. Medium-sized enterprises are located on the border of small and large companies.

The need to create new forms, such as small and medium-sized businesses, is conditioned not only by the development of market relations but also by the implementation of reforms in the country's 
economy, which is economically viable since the emergence of a large number of new companies entails the emergence of new jobs. In addition, revenues to budgets at all levels are increased by paying taxes and fees. Small business development is also necessary for large businesses, as small businesses give them a new life. Large businesses make big profits in tandem with small enterprises.

The development of the small and medium business sector is the basic and objectively necessary element of the country's socio-economic system. Small business is a "cell" of the market economy. The number of small businesses (including micro-enterprises) in Russia in 2016 was 2.770 .562 units. The number of such enterprises by type of economic activity is shown in Figure 1.

Figure 1: Number of small enterprises (including micro-enterprises) by types of economic activity in the Russian Federation in 2016, units.

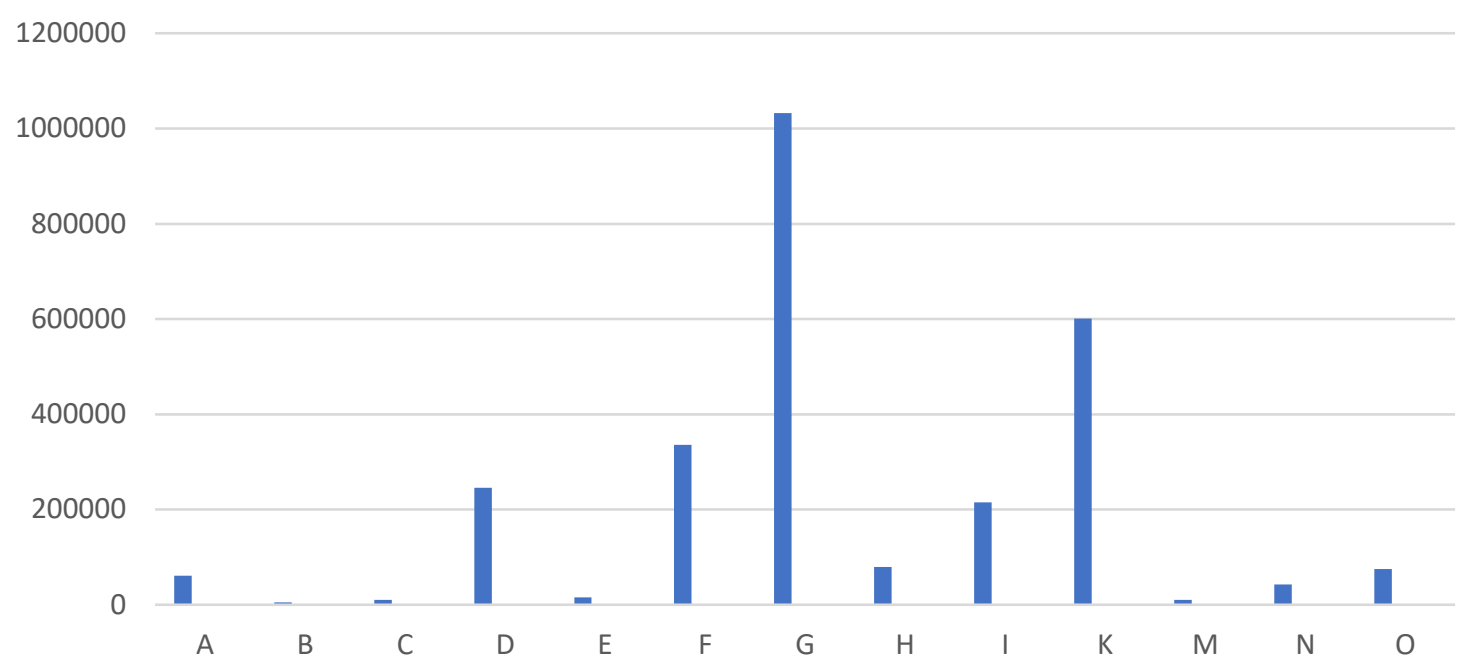

A - agriculture, hunting, and forestry; B - fishing; C - mining and quarrying; D - manufacturing; E electricity, gas and water supply; F - construction; G - wholesale and retail trade; repair of motor vehicles, motorcycles and personal and household goods; $\mathrm{H}$ - hotels and restaurants; I - transport and communications; $\mathrm{K}$ - real estate, renting and business activities; $\mathrm{M}$ - education; $\mathrm{N}$ - health and social work; $\mathrm{O}$ - other community, social and personal service activities

Source: Authors

Figure 2: Turnover of small enterprises (including micro-enterprises) by types of economic activity in the Russian Federation in 2016 (billion rubles).

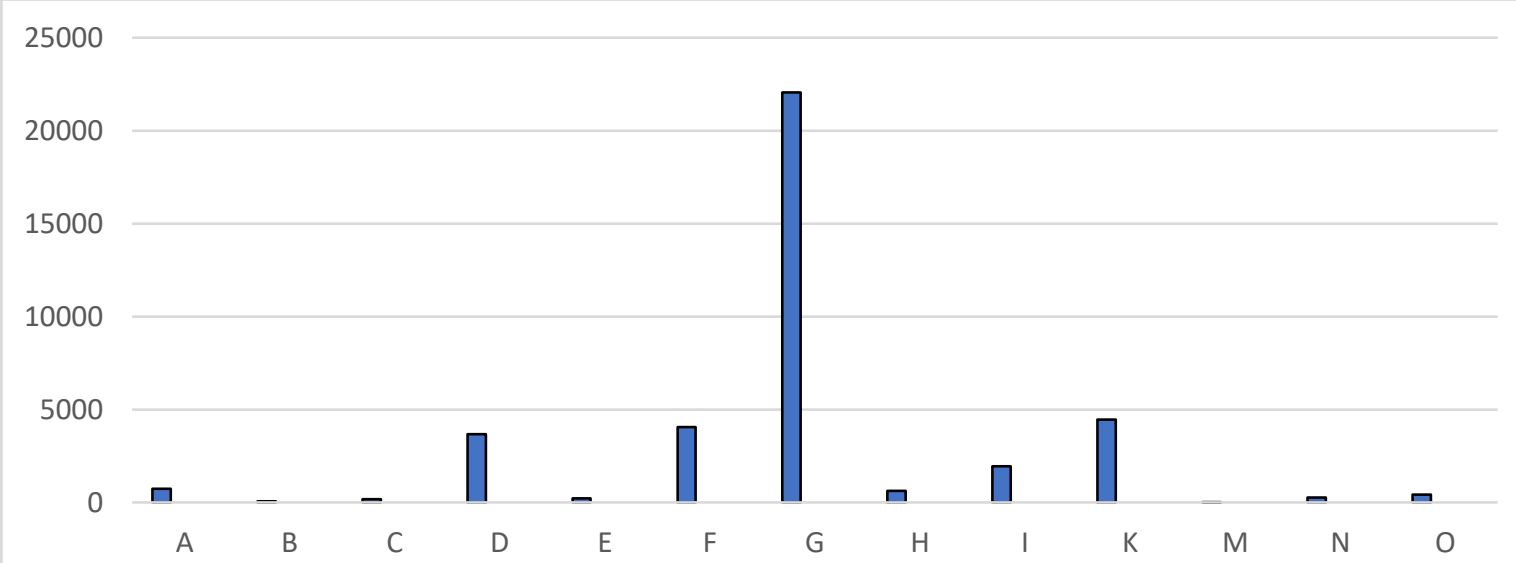

A - agriculture, hunting, and forestry; B - fishing; C - mining and quarrying; D - manufacturing; E electricity, gas and water supply; F - construction; G - wholesale and retail trade; repair of motor vehicles, motorcycles and personal and household goods; $\mathrm{H}$ - hotels and restaurants; I - transport and communications; $\mathrm{K}$ - real estate, renting and business activities; $\mathrm{M}$ - education; $\mathrm{N}$ - health and social work; $\mathrm{O}$ - other community, social and personal service activities

Source: Authors 
Most of these enterprises conduct wholesale and retail trade, motor vehicles, motorcycles, household products and personal items repair, various real estate transactions. In 2016, the turnover of small enterprises in Russia amounted to 38.877 billion rubles. The highest turnover is observed in the wholesale and retail trade; motor vehicles, motorcycles, household products and personal items repair. The turnover is slightly lower in real estate transactions, renting and business services, construction and manufacturing industries (see Figure 2).

According to data from the Ministry of Justice of the Russian Federation, the total number of nonprofit organizations was stable in 2015-2016, and the tendency directed towards definite growth. If in late 2015 its register contained about 226 thousand non-profit organizations, it accounted for over 227 thousand in December 2016.

The experience of countries with advanced market economies proves the objective need to develop an effective small and medium business sector in any national economy.

\section{Problems of differentiation between entrepreneurial and other activities}

The subjects of entrepreneurship are, first of all, entrepreneurs and commercial legal entities, but they can also be recognized as consumer cooperatives being non-profit organizations.

If there are no conflict-of-laws issues regarding the entrepreneurial activity of commercial organizations, there are certain practical problems with regard to the entrepreneurial activity of citizens. In particular, one of the features of entrepreneurial activity is the sign of the direction of systematic profit generation. At the same time, many citizens regularly perform certain works for a fee, for example, through trust agreements or work contracts. Legislative uncertainty of this feature leads to the fact that in practice it is impossible to explain why lessors of property are required to register it as business entities, and this requirement does not refer to contractors, despite the fact that their activities coincide in most cases, according to the features revealed by the literal interpretation of Art. 2 of the Civil Code of the Russian Federation.

The legislation of the Russian Federation has no concrete consistency in resolving the issue of delineation of entrepreneurial and other economic activities. So, the activity of the auditor is recognized as entrepreneurial, and the activity of the appraiser is considered to be professional.

In this regard, attention should be paid to the provisions of Art. 21 of the Federal Law № 273-FZ dated 29 December 2012 "On education in the Russian Federation", according to which educational activities are conducted by educational organizations and also by individual entrepreneurs. Analysis of the norms of this law allows us to make a conclusion that individuals who provide tutoring and provide educational services for an additional fee are recognized as entrepreneurs. At the same time, according to Art. 2 of the same Law, "an educational organization is a non-profit organization that conducts educational activities as core activities on the basis of a license in accordance with the objectives for the achievement of which such an organization has been created". As is known, the main activity of a non-profit organization is not profit-making. Accordingly, the educational activity of a non-profit educational organization is not entrepreneurial.

It is necessary to mention the right of a non-profit organization to carry out income-generating activities (para. 3 of Art. 50 of the Civil Code of the Russian Federation).

"Income-generating activity of non-profit organizations" is a term under discussion introduced in Art. 50 of the Civil Code of the Russian Federation in the process of reforming civil legislation. The possibility of non-profit organizations to carry out entrepreneurial activities was previously envisaged.

In this regard, most authors believe that the income-generating activities of non-profit organizations are inherently entrepreneurial or close to entrepreneurial the one. There is also a point of view, according to which income-generating activity is broader than entrepreneurial activity in its content.

It should be noted that the legislator himself, notwithstanding the introduction of the general rule on the possibility for non-profit organizations to perform only income-generating activities (Art. 50 of the Civil Code of the Russian Federation), nevertheless, establishes the possibility of exercising exclusively entrepreneurial activity with regard to an autonomous non-commercial organization (para. 5 of Art. 123.24 of the Civil Code of the Russian Federation). The foregoing inevitably raises the question of the correlation of concepts, features of entrepreneurial and income-generating activities. 
However, the Civil Code of the Russian Federation, like other federal laws, does not provide the definition of income-generating activities. In contrast, the legislator formulated the inherent characteristics of entrepreneurial activities in Art. 2 of the Civil Code of the Russian Federation: independence of implementation; risky character; the focus on systematic profit generation. The first two characteristics are inherent in income-generating activities as well. The scientific literature has references to it.

As for the direction to make a profit, in T.V. Soifer's view, an income-generating activity cannot have such a feature initially, since it is connected with the decision of any socially significant. But, in our opinion, this is not entirely correct, because if, for example, a non-profit organization systematically sales any goods, its goal will be to systematically generate a profit. The possibility of losses arising as a result of such activities will not be the determining factor here, since the goal of the conducted activity will be the defining purpose in this case, and not its result, as in the case of carrying out entrepreneurial activities by non-profit organizations.

Thus, income-generating activities can more or less have all the signs of entrepreneurial activity. But in some cases, it may not have them, for example, with a single income receipt by a non-profit organization. It should also be agreed with the opinion that income-generating activities include income from donations.

Proceeding from the above, the concept of income-generating activity is broader than the concept of entrepreneurial activity. Income-generating activities can be of two types: income-generating activities that have signs of entrepreneurial activity and income-generating activities that exclude their availability. At the same time, the legislation and judicial practice do not take into account the legal nature of these two types of income-generating activities distinct from each other.

\section{Conclusion}

Summarizing the above, it should be emphasized that there is a need to reform the legislation regulating the right of citizens and non-profit organizations to conduct entrepreneurial activities. It is revealed from the analysis of the norms of the Civil Code of the Russian Federation that there is a significant terminological contradiction associated with the legal implementation of an opportunity to realize the right of entrepreneurial activity, one of the major characteristics of this opportunity being direction to systematic profit-making by non-profit organizations which cannot have profit-making as the main objective of their activity.

Apart from this, para. 5 art. 123.24, para. 1 art. 1538 of the Civil Code of the Russian Federation uses the incorrect term "entrepreneurial activity of non-profit organizations".

Thus, the problem lies in the fact that the legislation uses semantically correlated terms "entrepreneurial activity", "activity pursuing profit-making" and "income-generating activities" not indicating the difference in their legal regulation.

The most rational solution of the existing situation is the unification of the terminology of laws and regulations when the regulator would uniformly use the term "entrepreneurial activity" related to commercial organizations and "income-generating activities" regarding non-profit organizations.

First of all, as it seems to us, it is necessary to bring its various provisions into conformity and establish clear criteria for distinguishing entrepreneurial activity from other types of economic activity.

It is also required to provide a clear definition of the concept of income-generating activities of nonprofit organizations at the level of the Federal Law of the Russian Federation № 7-FZ dated 12 January 1996 "On non-profit organizations" as follows: "income-generating activities are entrepreneurial and other activities of a non-profit organization aimed at generating income" and divide the legal regime of the two types of income-generating activities.

\section{References}

Grosul, Yu.V. (2013) O prave nekommercheskih organizacij na zanjatie predprinimatel'skoj dejatel'nost'ju [On the right of non-commercial organizations to conduct entrepreneurial activities]. Business law. Application "Business and law in Russia and overseas", $3,16-18$.

Kolesnikov, Y.A., Epifanova, T.V., Usenko, A.M., Parshina, E., Ostrovskaya, V.N. (2016) The peculiarities of state regulation of innovation activities of enterprises in the global economy. Contemporary Economics, vol. 10, 4, 343 - 352. 
Laptev V.V. (2003) Sub\#ekty predprinimatel'skogo prava. Uchebnoe posobie [Subjects of business law. Tutorial], Moscow, Jurist', 236 p.

Official site of the Federal State Statistics Service of the Russian Federation (2016). Russia in figures / Entrepreneurship. Available at: http://www.gks.ru/wps/wcm/connect/rosstat_main/rosstat/ru/statistics/ enterprise/

Salina, L. Pozhertvovanija kazennomu uchrezhdeniju ot fizicheskih i juridicheskih lic [Donations from individuals and legal entities to public organizations]. Public organizations: accounting and taxation, 10, $28-36$.

Shatkovskaya, T.V., Epifanova, T.V. (2016) Correlation of private and public legal interests as theoretical and scientific and practical problems of modern law. Journal of Advanced Research in Law and Economics, vol. 7, 3, 625 - 643.

Shaydurov, I.V. (2016) Prinosjashhaja dohod dejatel'nost' v grazhdanskom zakonodatel'stve Rossii [Income-generating activity in the civil law of Russia]. Rule of Law, 3, 199 - 206.

Soifer T.V. (2016) Jekonomicheskaja dejatel'nost' nekommercheskih organizacij i ee grazhdansko-pravovoe obespechenie [Economic activity of non-commercial organizations and its civil and legal support]. Journal of Russian Law, 1, 22 - 30.

Spector, A.A. (2012) K voprosu o kategorijah «sub\#ekt predprinimatel'skoj dejatel'nosti» i «sub\#ekt predprinimatel'skogo prava» [To the issue of categories of a "business entity" and a "subject of business law"]. Business law. Application "Business and law in Russia and overseas", 2, 40 - 43.

Zvezdina, T.M. (2014) K voprosu o sootnoshenii ponjatij predprinimatel'skoj i prinosjashhej dohod dejatel'nosti nekommercheskih organizacij [To the issue of correlation between the concepts of entrepreneurial and income-generating activities of non-commercial activities]. Business, Management and Law, 2, $72-75$. 